\title{
Looking for the traces of the last hunter- gatherers: Geophysical survey in the Mesolithic shell middens of the Sado valley (southern...
}

Article in Quaternary International · March 2016

DOI: 10.1016/j.quaint.2016.02.016

\section{CITATION}

1

8 authors, including:

\section{Pablo Arias}

Universidad de Cantabria

111 PUBLICATIONS 664 CITATIONS

SEE PROFILE

\section{Miriam Cubas}

Aranzadi Science Society

98 PUBLICATIONS 141 CITATIONS

SEE PROFILE
READS

212

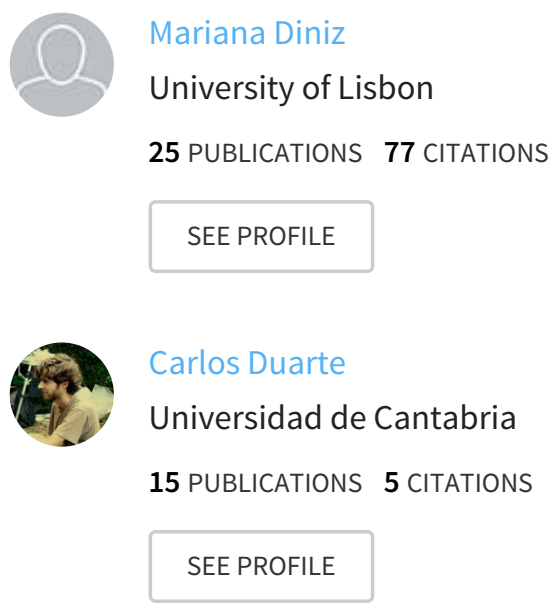

Some of the authors of this publication are also working on these related projects:

Estudio de sitios con expresión gráfica prehistórica postpaleolítica en la comarca de Campoo-los 


\title{
Looking for the traces of the last hunter-gatherers: Geophysical survey in the Mesolithic shell middens of the Sado valley (southern Portugal)
}

\author{
Pablo Arias ${ }^{\text {a, * }}$, Mariana Diniz ${ }^{\mathrm{b}}$, Miriam Cubas ${ }^{\mathrm{c}}$, Carlos Duarte ${ }^{\mathrm{a}}$, Eneko Iriarte ${ }^{\mathrm{d}}$, \\ Christoph Salzmann ${ }^{\mathrm{e}}$, Felix Teichner ${ }^{\mathrm{e}}$, Luis Teira ${ }^{\mathrm{a}}$ \\ a Instituto Internacional de Investigaciones Prehistóricas de Cantabria, Universidad de Cantabria, Av. de los Castros 52, 39005 Santander, Spain \\ ${ }^{\mathrm{b}}$ UNIARQ Faculdade de Letras, Universidade de Lisboa, 1600-214 Lisboa, Portugal

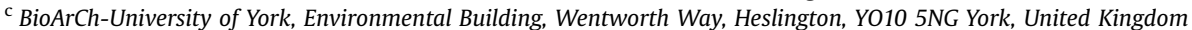 \\ ${ }^{\mathrm{d}}$ Laboratorio de Evolución Humana, Dpto. Ciencias Históricas y Geografía, Universidad de Burgos, Plaza de Misael Bañuelos s/n, Edificio I+D+I, 09001 \\ Burgos, Spain \\ e Philipps-Universität Marburg, Fachbereich Geschichte und Kulturwissenschaften, Vorgeschichtliches Seminar, Biegenstraße 11, 35037 Marburg, Germany
}

\section{A R T I C L E I N F O}

Article history:

Available online $\mathrm{xxx}$

\section{Keywords:}

Magnetometry

Mesolithic

Neolithic

Shell middens

Archaeological survey

\begin{abstract}
A B S T R A C T
This paper presents the results of an application of geophysical surveying methods to Mesolithic sites in Portugal. Magnetic gradiometry maps have been produced at the sites of Vale de Romeiras and Poças de São Bento. At the latter, three excavation seasons have provided information to test the results of the survey. It is concluded that these techniques can be considered efficient tools for the delimitation of the sites and for the identification of Mesolithic and Neolithic structures.
\end{abstract}

(c) 2016 Elsevier Ltd and INQUA. All rights reserved.

\section{Introduction. The shell middens of the Sado valley}

The Sado shell middens are among the most outstanding points of reference for the European Mesolithic. Twelve open-air Mesolithic sites are known in the lower sector of this valley, most of them including concentrations of human burials, and even cemeteries, dating to the late seventh and the sixth millennia cal BC. The sites are spread along $15 \mathrm{~km}$ on both banks of the valley of the River Sado (Fig. 1), which crosses a Tertiary basin opened in the chiefly Palaeozoic landscape of Alentejo, in southern Portugal. As has been frequently highlighted, the settlement is surprisingly upstream (41-57 km from the current mouth of the river near Setúbal) for sites that are usually described as "shell middens". This has usually been explained by the supposed existence of a very deep postglacial palaeoestuary (see, for instance, Arnaud, 1989, p. 627), although recent research suggests that this interpretation should be revised (Arias et al., 2015b).

Discovered in the 1930s, the Sado Mesolithic sites were extensively excavated in the 1950s and the 1960s by Manuel Heleno, then

\footnotetext{
* Corresponding author.

E-mail address: pablo.arias@unican.es (P. Arias).
}

the director of the National Museum of Archaeology (Museu Nacional de Arqueologia), and some members of his team (Heleno, 1956; Santos et al., 1974; Soares, 2013). A revision of the mainly unpublished data from Heleno's research and new excavations in the sites of Cabeço das Amoreiras, Cabeço do Pez and Poças de São Bento, the latter in collaboration with Lars Larsson, were attempted by José Morais Arnaud in the 1980s (Arnaud, 1989, 1990; Larsson, 1996, 2010). However, this promising programme was interrupted before its completion, and the Sado Mesolithic sites were nearly forgotten, in spite of some partial analyses of the archaeological material stored in the Museu Nacional de Arqueologia (Araújo, 1995-1997; Cunha and Umbelino, 1995-1997; Marchand, 2001; Umbelino, 2006; Diniz, 2010; Nukushina, 2012; Umbelino and Cunha, 2012). In 2010, a new research programme on the Mesolithic of this area was launched, the SADO MESO project, directed by two of the authors of this paper (P.A. and M.D.) It is included in a larger programme of research, analysing the processes of transition to the Neolithic in three coastal areas of Atlantic Europe: Brittany, northern Spain and southern Portugal (see the acknowledgement section for details). Within the framework of this new project, a systematic revision of the Sado Mesolithic has been started, including palaeoenvironmental research, a 


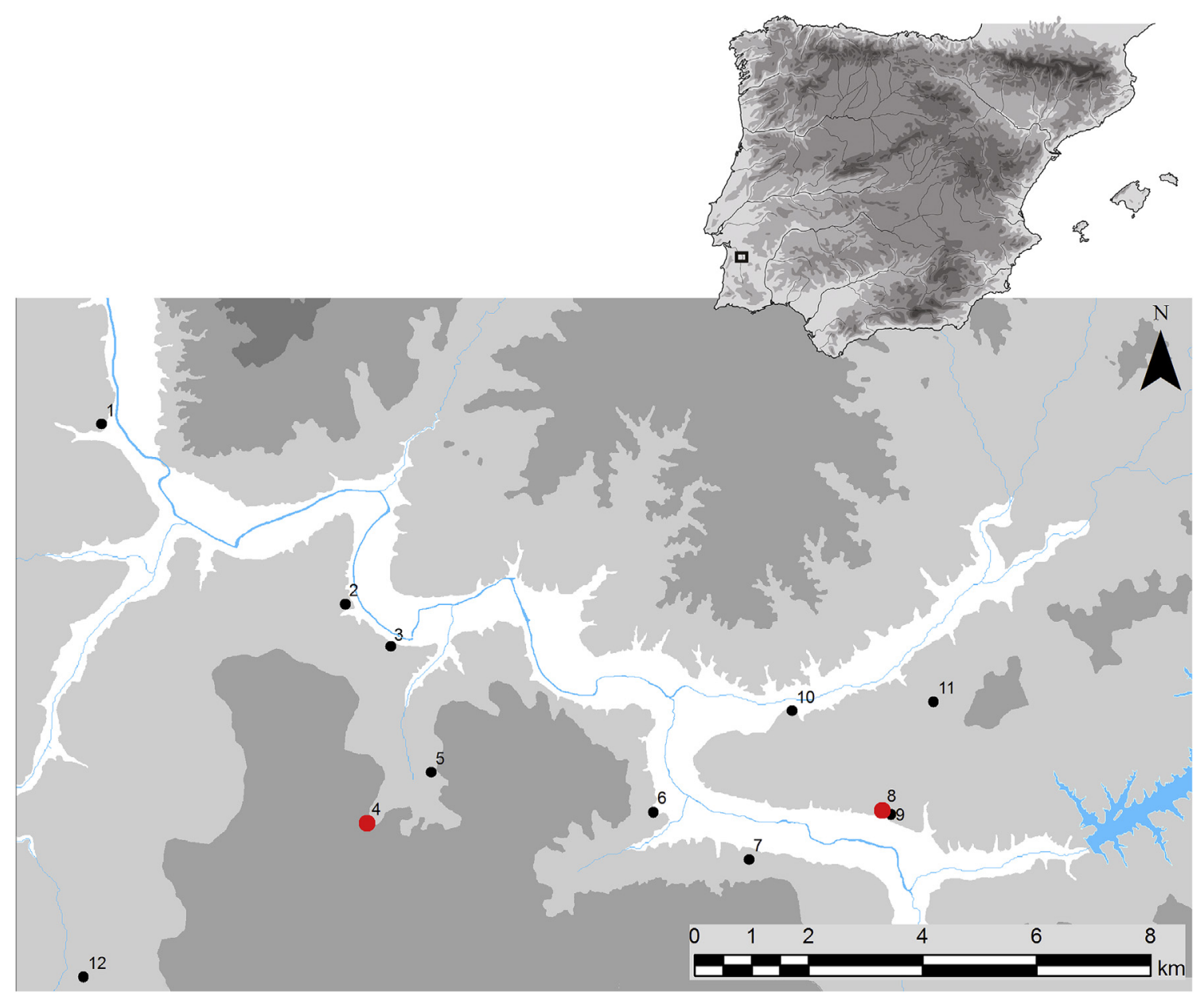

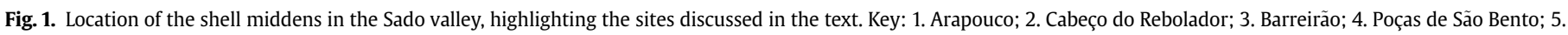
Fonte da Mina; 6. Barrada das Vieiras; 7. Cabeço das Amoreiras; 8. Vale de Romeiras; 9. Cabeço do Pez; 10. Várzea da Mó; 11. Barrada do Grilo; 12. Barranco da Moura.

systematic archaeological survey of the region, and excavations at the sites of Poças de São Bento, Cabeço do Pez and Cabeço das Amoreiras (Diniz and Arias, 2012; Araújo et al., 2015; Arias et al., 2015b; Diniz and Cubas, 2015; Duarte et al., 2015; López-Dóriga et al., 2015; Pimentel et al., 2015). In this paper we will focus on the geophysical survey in two selected sites: Poças de São Bento and Vale de Romeiras.

\section{An overview on the surveyed sites}

As stated above, the Sado shell middens are located in the lower section of the valley. They are typically situated on the edge of small plateaus some $60 \mathrm{~m}$ above the river, with a good visual control over ample sectors of the valley (Fig. 2). Only three sites were located at lower altitudes above the river - Barrada do Grilo, Barradas das Vieiras and Várzea da Mó, which are just at 8-20 m -, whereas Poças de S. Bento is in a slightly different location, on top of the $80 \mathrm{~m}$ tableland, but $2.5 \mathrm{~km}$ from the main river, on the left bank of a small brook. Due to this kind of location, aquatic resources were not available in the close vicinity of the sites, and therefore some effort had to be involved in food transport, especially in the case of Poças de S. Bento.

The geological setting of the sites is quite homogeneous (Pimentel et al., 2015). Typically, they are located above Pleistocene sandy layers (in some cases real dunes) covering the Tertiary bedrock formed mainly by sandstone and conglomerates. As a result of this, the Mesolithic layers are usually sandy deposits with variable concentration of anthropogenic material: mainly Scrobicularia plana and Cerastoderma edule shells, but also charcoal, mammals and fish bones, lithic and bone industries and other less visible pieces of evidence such as seeds, micromammals, insects ... The excavations performed in these sites, especially those applying modern recording techniques, have shown that they include many

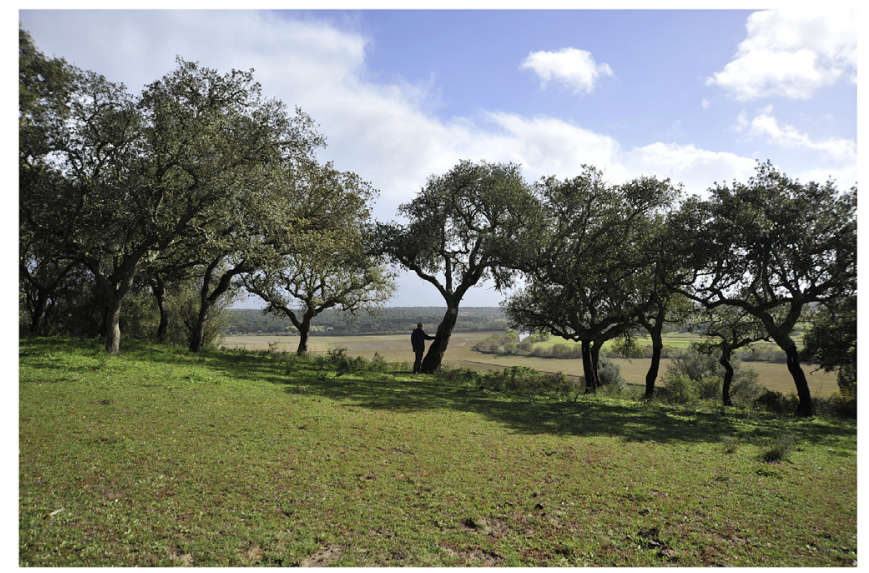

Fig. 2. Mesolithic site of Vale de Romeiras. Note the wide visual control of the bottom of the valley from the site. 
archaeological features (pits for different functions, including burials, hearths ...). Yet frequently they are not easy to recognise in the excavation, and they are completely invisible on the surface. Moreover, most of the sites appear to be quite large and their limits are very difficult or even impossible to establish, as they are not in the form of mounds. Prior to an archaeological intervention, a typical Sado shell midden is just a relatively even surface (Figs. 2 and 5) where variable concentrations of shell fragments can be observed on the ground. Thus, an insight into what is hidden below that largely opaque surface is required for a more precise definition of the site limits and for efficient planning of the excavations. Two techniques have been tested within the framework of this project: magnetic gradiometry surveying and sediment cores. Two sites were selected that might be considered representative of the variability of the Sado Mesolithic sites: Vale de Romeiras and Poças de São Bento. On the one hand they are located in the two kinds of geographic setting (Vale de Romeiras is in the typical position above the river, whereas Poças de São Bento lies in the inner part of the plateau); on the other hand, according to Heleno's record, Vale de Romeiras might have been mainly a burial site, while Poças de São Bento is a much more complex settlement including a base camp together with burials.

\subsection{Vale de Romeiras}

With an estimated area of about $54 \mathrm{~m}^{2}$, Vale de Romeiras is, according to previous fieldwork, the smallest shell midden in the Sado valley. The site was, apparently, totally excavated by Manuel Heleno's, team. Located on the right bank of the Sado, on a tableland $60 \mathrm{~m}$ high above the river (Fig. 2), it is, together with the neighbouring and much larger site of Cabeço do Pez - only $300 \mathrm{~m}$ to the east - and Barrada do Grilo, among the Sado shell middens which are furthest from the coast.

The unpublished Museu Nacional de Arqueologia excavations carried out during the 1950s were later partially revised by Arnaud (1989), revealing that, in spite of the restricted size of the site, twenty-two burials were retrieved, arranged in a semi-circle facing the river. That led Arnaud to suggest that Vale de Romeiras might have been the cemetery for Cabeço do Pez. Further analysis of the human remains permitted the determination of a minimal number of individuals (MNI) of twenty-six (Cunha and Umbelino, 2001). The stratigraphy recorded by Heleno and his team shows the typical sequence of the Sado Mesolithic sites: one or two layers of brown soil covering shell middens deposits that overlaid yellowish sands (Arnaud, 2000, Fig. 9). The corpses were buried either in the basal sandy layer or in the shell midden. It has been highlighted that the density of burials at Vale de Romeiras is much higher than in any other site in the Sado (Arnaud, 1989, Table 2; Cunha and Umbelino, 2001, Table 1). Compared with a ratio of one burial per $16.6 \mathrm{~m}^{2}$ at Arapouco and one per $111 \mathrm{~m}^{2}$ at Cabeço do Pez, at Vale de Romeiras we find an amazing ratio of one per $2.5 \mathrm{~m}^{2}$ (Arnaud, 1989). Yet this contrast largely depends on the accuracy of the estimations about the size of the surface area at Vale de Romeiras obtained from calculations based on the 1950s fieldwork. That should be tested in the context of the current reanalysis of the Sado Mesolithic. With that aim, the site was selected for the geophysical survey.

\subsection{Poças de São Bento}

As mentioned above, Poças de São Bento is located on the top of a plateau, some $3 \mathrm{~km}$ south of its edge. However, it is near a rivulet which runs to the north towards the Sado. The archaeological site is just a few metres ahead of a series of small permanent ponds (that is the meaning of the Portuguese toponym "Poças"), which, according to our geomorphological analysis, were available during the middle Holocene, and were probably among the reasons that justify Prehistoric human settlement in that particular place (Pimentel et al., 2015). The shell midden is judged to be one of the largest Mesolithic sites in the Sado $\left(3500 \mathrm{~m}^{2}\right)$, although the limits were difficult to assess because, as stated above, the archaeological deposit does not exhibit any particular feature on the surface. This is quite even, although the site is located on a gentle slope descending from a low height dominating the area to the edge of the valley of the rivulet. Within the framework of the SADO MESO project, a total surface of $59.5 \mathrm{~m}^{2}$ has been excavated, distributed quite evenly across the area (Fig. 7). Although some lateral variations were found, especially in the thickness of the layers, the stratigraphy was quite consistent in most of the excavation areas. From bottom to top the following units were distinguished (Fig. 3):

- Geological Substrate: Cenozoic ferruginous reddish or yellowish sandstone and sands.

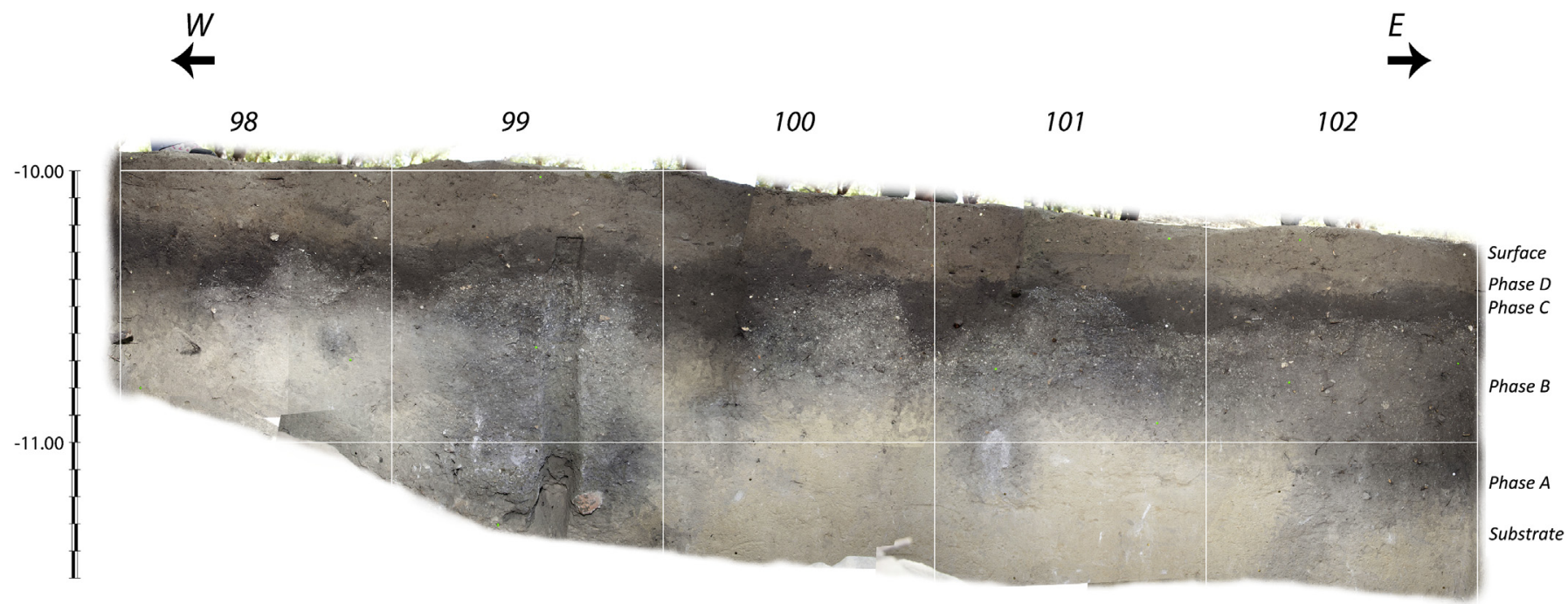

Fig. 3. Poças de São Bento. Orthoimage of the northern profile of excavation area 1, showing the archaeological units distinguished during the excavation. 
- Phase A: Greyish sands with a low density of shells and lithics.

- Phase B: Dense accumulation of mollusc shells (mainly Scrobicularia plana and, in a smaller proportion, Cerastoderma edule) in a sandy sediment with a low density of other kinds of archaeological materials. Several radiocarbon dates locate this phase between the late seventh millennium cal BC and the mid sixth millennium.

- Phase C: Blackish sand with some allochthonous sandstone blocks, a low density of shells and sparse archaeological material, including lithics, bones and some Neolithic pottery sherds. It appears to correspond to the upper horizon of a palaeosol. Radiocarbon dates, consistent with the style of the pottery, confirms an early fifth millennium cal BC chronology.

- Phase D: Yellowish sand with a low density of archaeological remains, including some modern pottery.

- Surface. Modern soil.

Research at Poças de São Bento also included the extraction of four sedimentological cores (PSB-A to PSB-D-see Fig. 7), 2 m deep, taken with a percussion window sampler with a Van Walt/Eijkelkamp mechanical corer. Once in the laboratory they were longitudinally sectioned, photographed, analysed and sampled. The geochemistry was analysed using an Avaatech XRF Core-scanner, which provided useful information regarding the chemostratigraphic variations and environmental change (see Duarte et al., 2015 for details). No significant differences have been found among the sequences recovered in those cores. Along their sequence the following chemostratigraphic units have been observed (Fig. 4) (from bottom to top):

- Phase 1: Plio-Pleistocene sand substrate, showing evidence of aeolian sedimentation in a dune system, characterized by the absence of vegetation and, subsequently, no development of soils.

- Phase 2 (Units F and E): Significant increase in anthropogenic elements. Unit $\mathrm{F}$ displays a gradational enrichment of $\mathrm{Ca}$ (coming from shells) and organic matter $(\mathrm{Br}, \mathrm{P})$, that continues in the overlying Unit E. Unit $\mathrm{F}$ is not affected by pedogenetic activity, whereas Unit E, the upper and denser shell midden level, is characterized by the highest values of shell carbonates (Ca), increasing organic matter derived elements $(\mathrm{Br}$ and $\mathrm{P})$ and a gradual enrichment in pedogenic elements $(\mathrm{Fe}, \mathrm{Al})$, probably related to soil development in the overlying Unit D.

- Phase 3 (Unit D): Palaeosol. It displays the maximum values of organic matter proxies ( $\mathrm{Br}$ and $\mathrm{P}$ ) and an abrupt loss of calcium due to the lower density of (shells). It can be interpreted as an evolved surficial A horizon of a vegetated palaeosol developed after the sedimentation of shell-rich sediments in Unit E.
- Phase 4 (Units C and B): Aggradational soil sequence, resulting from erosion/sedimentation cycles and the development of incipient soil sequences marked by high pedogenic activity and oxidizing processes (Fe). This may reflect drier and cooler climatic conditions, as observed in the environmental record on the nearby coast (Costas et al., 2012).

- Phase 5 (Unit A): It represents the anthropogenic stabilization of the surface in historic times and present-day soil use. It is characterized by low values of $\mathrm{Ca}$ and $\mathrm{Br}$ (carbonates and charcoal) and a high P content, indicating that the organic matter in this horizon is related to plant remains. The presence of lithophile and oxidizing elements suggests a high pedogenic activity.

As can be observed, the chemostratigraphic division closely matches the archaeological sequence, established on an independent basis during the excavation. This approach supports the interpretation of the Poças de São Bento stratigraphic sequence as an aggradational soil record, formed by the intercalation of buried palaeosols and aeolian sediments that reflect different intensities of vegetation, substrate stabilization and aeolian activity during the Holocene. These sediments include the remains of human activity in the Mesolithic, particularly in Units F and E, mainly reflected by the addition of shells and charcoal, during a changing environment towards more humid and warmer climatic conditions.

\section{Magnetometry survey}

Magnetometry is a well-known method based on the measurement of the local variation from the hypothetically smooth magnetic field of the earth, so that it can be used for the localization and the systematic archaeological mapping of archaeological sites (Scollar et al., 1990; Zickgraf, 1999; Neubauer, 2001; Linford, 2006; Witten, 2006). In most types of soils the concentration of magnetic minerals varies in the different horizons, and it is usually higher in the upper part. Anthropogenic alterations of the soil structure, such as pits, ditches, postholes, foundations, trenches or burials, may result in the mixing of different horizons, thus producing measurable differences from the "normal" magnetic values of the area. Therefore, those kinds of anthropogenic features may be recognized by the magnetometry survey. A similar effect may also be produced by changes in the composition of the soils such as the accumulation of shells.

Fieldwork was performed on 21 and 22 February 2013 by a team from the Prehistory and Archaeology Department of the PhilippsUniversity at Marburg (C.S. and F.T.), with the collaboration of the Frankfurt branch of the German Archaeological Institute (RömischGermanische Kommission). A 5-channel carrier for manual use,

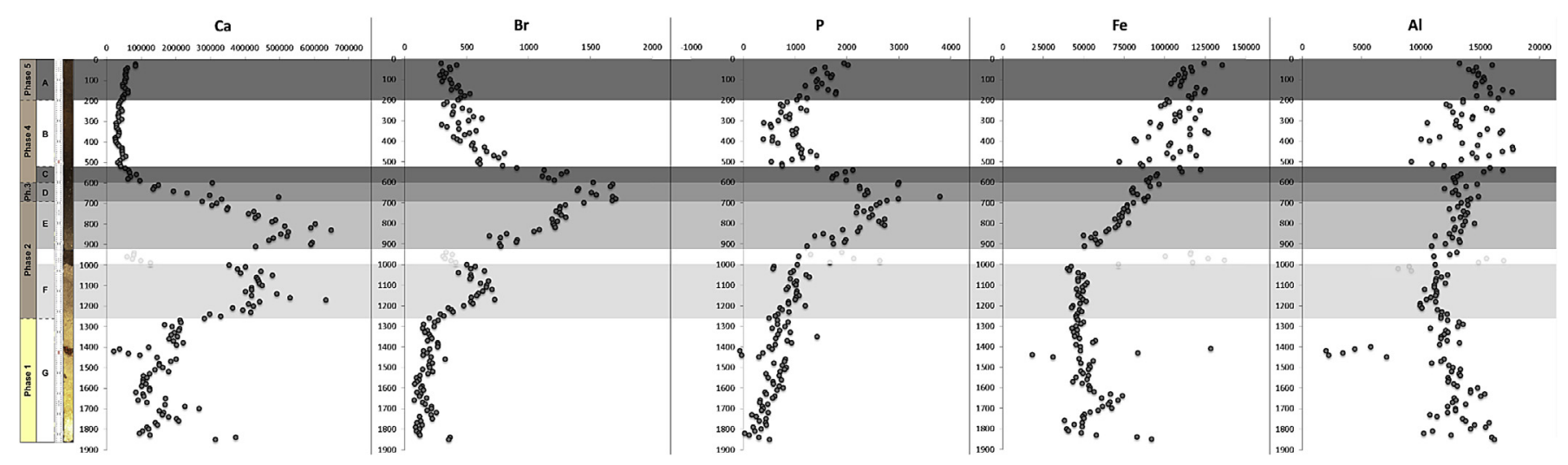

Fig. 4. Poças de São Bento. Chemostratigraphic analysis of core PSB-D. 
suitable for small or medium-sized areas, was used. The data recording was done inside a traditional rectangular grid laid over the surveyed area. This system had already been tested with excellent results by our team in the Iberian Peninsula, at several Iron Age and Roman sites ((Cepeda et al., 2009a, 2009b; Teichner et al., 2014; Teichner et al. 2015) and also at Mesolithic sites of eastern Asturias, where a similar research was done within the framework of this project (Arias et al., 2015a). We used MAGNETO $^{\circledR}$-ARCH-5-channel-system, an instrument produced by the firm SENSYS Sensorik \& Systemtechnologie GmbH (Bad Saarow, Germany). It is a kind of two-wheel barrow that is pushed over the area (Fig. 5). The multi-channel magnetometer system uses five probes of the FGM-650/3 type. The measuring range is $\pm 3000 \mathrm{nT}$ and its accuracy is $0.1 \mathrm{nT}$. The distance between the probes was

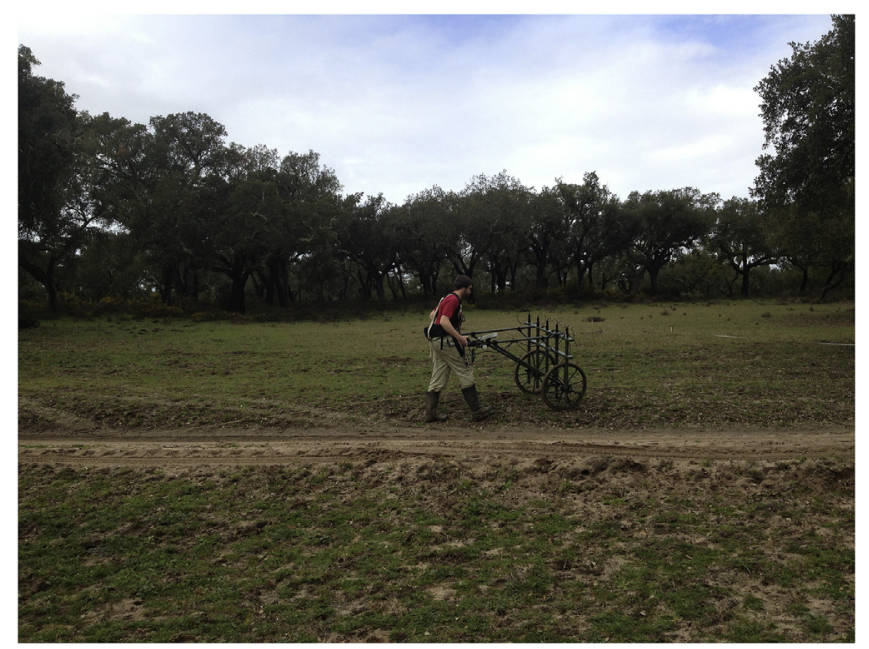

Fig. 5. Geophysical survey at Poças de São Bento.

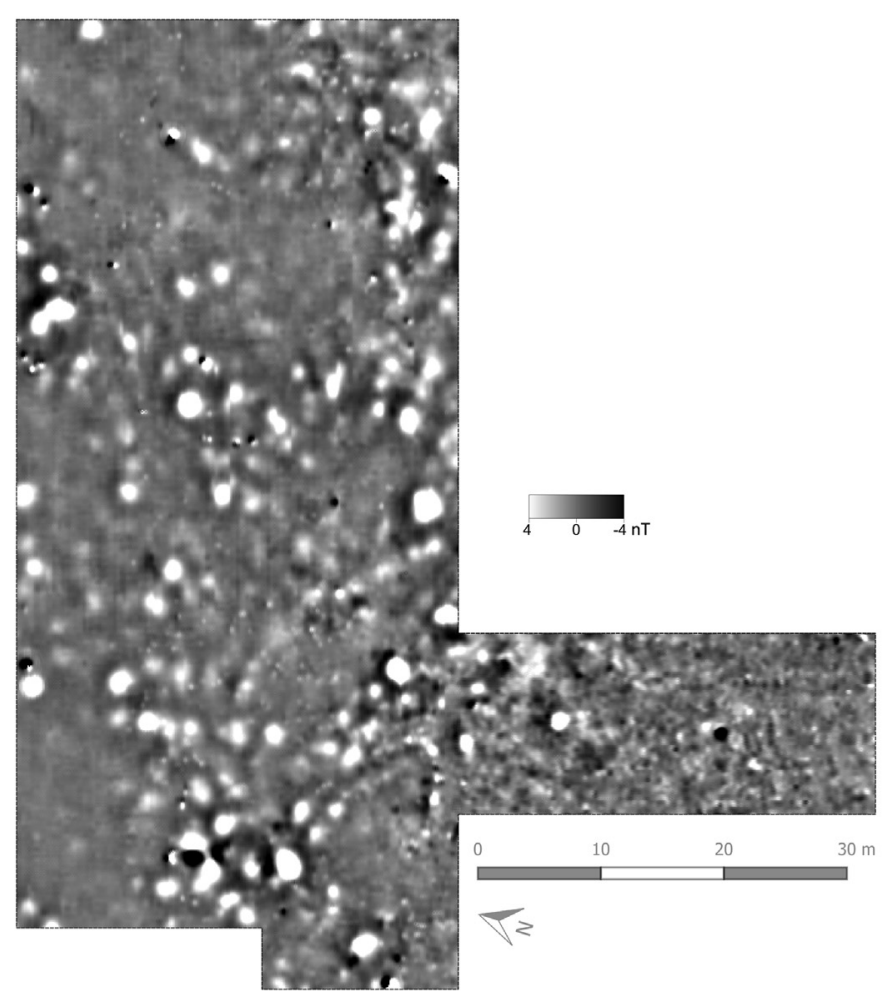

$25 \mathrm{~cm}$, thus allowing the simultaneous measurement of bands $1 \mathrm{~m}$ wide. Each probe took one measurement every $10 \mathrm{~cm}$. The travelled distance was documented by an odometer, which was fixed to one of the wheels. At the sites, adequate rectangular grids were laid out, always attempting to cover as much of the expected archaeological features as possible, and at the same time to avoid potential objects of disturbances such as trees, fences or, in the case of Poças de São Bento, previous excavation pits. The measurements of the limits and the orthogonal axes of these rectangular areas were established with a total station. Their corners were georeferenced within the coordinates system of the excavation, allowing us to easily relate raster anomalies with physical reality susceptible of being excavated. After marking out the fields and assembling and calibrating the magnetometer, lines with $1.25 \mathrm{~m}$ intervals were set, and they were explored following the so-called ox-turning style ( the following line in an inverse direction.

In Poças de São Bento an area of $4372 \mathrm{~m}^{2}$ was surveyed. Staking the prospecting areas was not easy because there are a lot of trees. In Vale de Romeiras we were able to examine an area of $3245.5 \mathrm{~m}^{2}$ with the magnetometer. For each measurement this device saves three coordinates, $\mathrm{x}, \mathrm{y}$ and the magnetization, which are exported to a text file by the software MAGNETO ${ }^{\circledR}$. From those data, a raster image was generated, using "gvSIG-OA" open source GIS software. The raster image was calculated with the aid of the GRASS tool "r.in.xyz". Then the raster images were interpolated with the help of the GRASS tool "r.fill.gap". After the processing, we were able to start the interpretation of the geophysical survey. For the representation of the magnetization, different ranges of nanotesla (nT) values were essayed in order to improve the understanding of potential anomalies.

At Vale de Romeiras the survey could be carried out on a fairly large open space (Fig. 6). Most of the measured area is situated on a plateau, which begins to change towards a steep slope to the south. No relevant disruptive elements were observed, except for

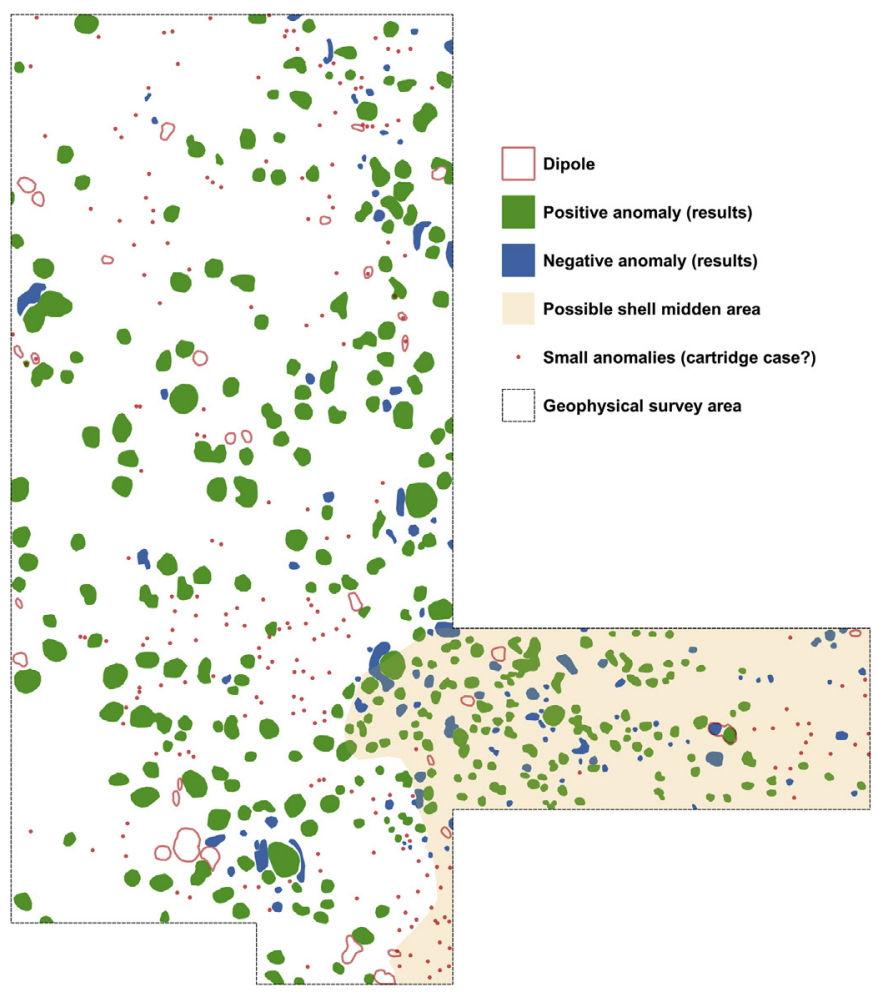

Fig. 6. Vale de Romeiras. Results of the magnetometry survey (left) and its interpretation (right). 
cartridge cases that were scattered on the ground (currently Romeiras is used as a training area for hunting dogs). The impact of these small pieces of metal in the measurement results can only be guessed, although many low anomalies (most of them positive) that were observed might have been produced by them. The most outstanding feature at Vale de Romeiras is the difference in "background noise" between two areas (represented in white and sepia in the image at the right side of Fig. 6). It might be attributed to differences in the densities of shell remains: the "sepia area" corresponding to the shell midden, and the rest to other areas in the Mesolithic settlement. As a matter of fact, the occurrence of fragments of shell on the ground tends to concentrate in the former. If that hypothesis is confirmed, the current interpretation of the site, as a very small, probably mainly funerary, site should be revised. Furthermore it can be noticed there are scarce large anomalies in the supposed shell midden area, but only on the plateau.

At Poças de São Bento, the general distribution of the anomalies appears to be related to human activities, permitting to identify the area covered by the Prehistoric settlement (Fig. 7). Most of them can be observed on the flat area east of the track. Looking west towards the slope more anomalies can be discerned. Yet, whereas the southern limit appears to be quite clear, the northern one is more diffuse, probably because it is located near the end of the measured area. There is no evidence whether further anomalies are still to be found east of the flat area, as the beginning of a very steep slope towards the brook and the vegetation prevented further examination of that area. Overall the measurement image is impaired by the road, the topography rods, previous excavation trenches and other minor faults (represented in the survey by dipoles). In the south of the area a weak elongated anomaly (low nanotesla measurement) was found, running down the slope from northwest to southeast. This anomaly may be identified as an erosion gully. The possible archaeologically-relevant anomalies (highlighted in Fig. 7 - right as "positive anomaly" and "negative anomaly") present a diffuse picture, making their interpretation difficult. To complement the graphic in Fig. 7, based on the nanotesla values, we have elaborated a second one attending to the size of the anomalies (Fig. 8). This interpretative approach is subject to many subjective factors (representation of nanotesla areas, selected size of the redrawing of anomalies, mutual influence of the anomalies). Nevertheless, it highlights the existence of possible patterning of the distribution of anomalies in the site. As a preliminary (and highly speculative) hypothesis, we would suggest that the concentrations of the largest anomalies $\left(>1.5 \mathrm{~m}^{2}\right)$ in the central and northern part of the surveyed area might correspond to denser accumulations of anthropogenic residues, probably shell midden deposits. On the other side, the aggregations of the smallest anomalies that can be observed in some areas, particularly in the centre and the east, might reflect features such as pits or activity areas.

\section{Testing the geophysical results. The archaeological excavations at Poças de São Bento}

The archaeological excavations that we are developing at the site of Poças de São Bento provided an excellent occasion to test the results of the geophysical survey. During the 2013, 2014 and 2015 seasons, several test pits were opened in areas where geomagnetic anomalies had been detected. We selected a series of anomalies

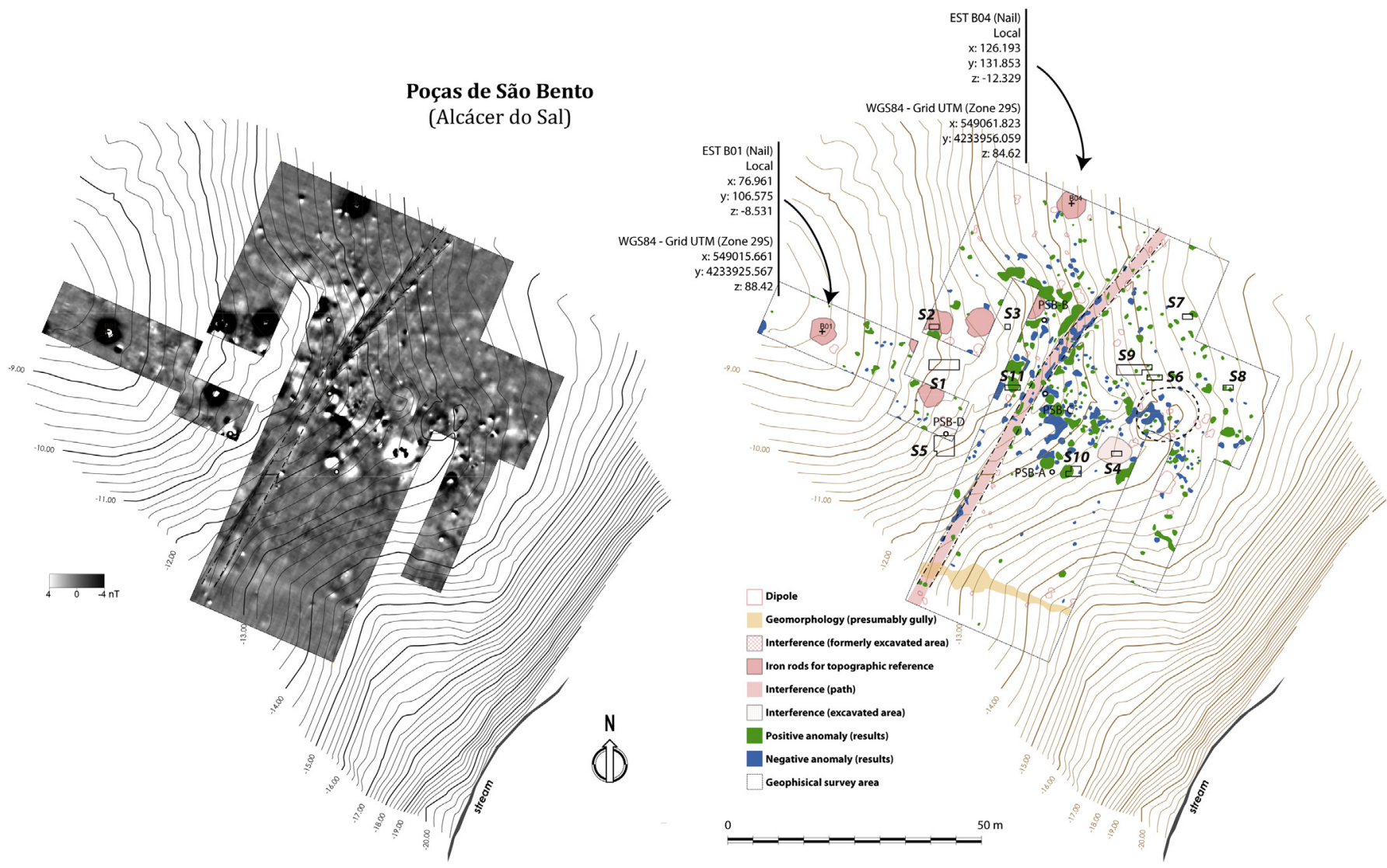

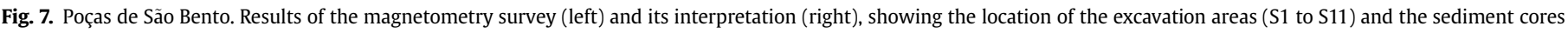
(PSB-A to PSB-D). 
that, according to their magnetic values and their size, might correspond to Mesolithic features. As the raster image was georeferenced within the local coordinates system of the excavation, it was possible to locate them in the field with a total station. An initial examination was later made on the surface, which led us to discard one of the apparently most promising features: a large oval positive anomaly located near the southern extreme of the surveyed area (close to the -14 contour line in Fig. 7 and 8). On the surface it appeared as a small mound, which we attributed to a spoil heap of one of the previous archaeological excavations at the site.

Two positive anomalies located in the NE sector of the site, some $10 \mathrm{~m}$ north of the main Arnaud-Larsson excavation area, were then explored. A new excavation area (S6) was opened up. It was a $3 \times 1 \mathrm{~m}$ test pit, oriented from west to east. The excavation,

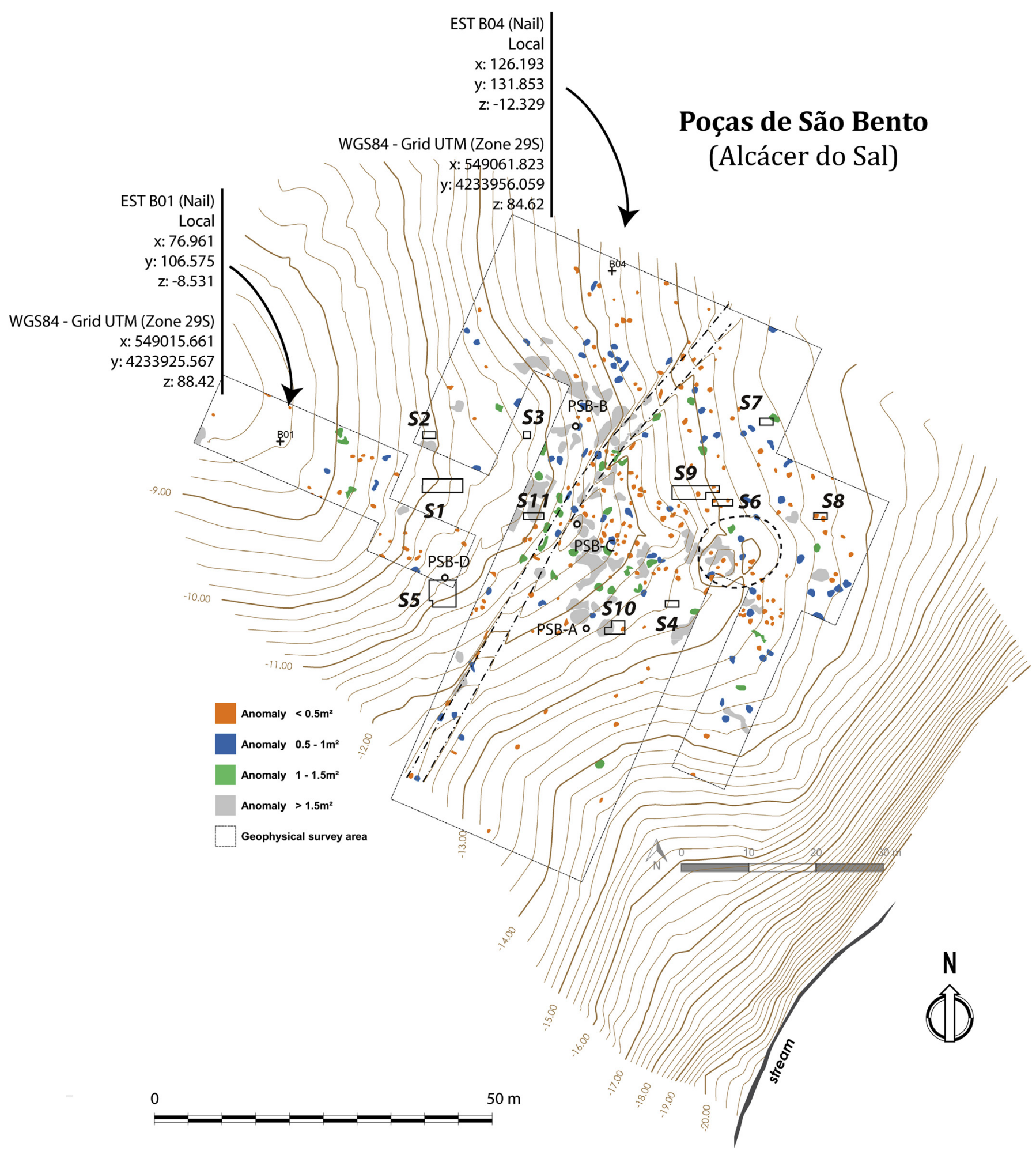

Fig. 8. Poças de São Bento. Magnetic anomalies sorted by their size. 
following the protocol systematically applied in the project (Arias et al., 2015b), revealed a stratigraphic sequence which was very similar to that found in other sectors of the site. It started with the surface layer (SU 601), followed by the yellowish sand corresponding to Phase D (see above) (SU 602). Below it, a blackish layer (SU 603) was extended across the whole surface of the trench. This stratigraphic unit appeared to be the upper horizon of a palaeosol (Phase C). In some sectors where the shell midden did not exist, a lighter layer of sand appeared below, probably corresponding to a lower horizon of the same soil. In other areas, especially in the western part of the trench, this soil covered several discrete sedimentary units characterised by high density of marine shells (SU $604,605,607$ and 610). In some cases, those shell midden fragments consisted of an upper part defined by a dark colour and a high concentration of shells (SU 604, 605, and 610) superposed on lighter and more sandy sediment (SU 612, 615 and 611, respectively). However, the most relevant part was SU 607. This layer, concentrated in the western part of the trench, was covering an accumulation of dark brownish sand without shells or with a very low density of them (SU 613), filling a vertical negative unit (SU 614 ), a pit excavated in the sterile geological substrate (the Pleistocene sand SU 617, covering the Pliocene bedrock-sandstone) where a primary human burial was found. The spatial coincidence between this burial and one of the positive anomalies detected by the geophysical surveying suggests that the latter was produced by the anthropogenic alteration of the soil structure due to the opening and refilling of the burial pit.

The test pit in excavation area 7 was not so successful. It was opened in an area some $15 \mathrm{~m}$ to the NNE of Area 6 where some large anomalies had been detected. There, a $2 \times 1 \mathrm{~m}$ trench, oriented from west to east, was excavated in 2014. The stratigraphy showed an accumulation of sandy sediments where two pedogenetic cycles could be recognised below the current soil. It was nearly sterile from the archaeological point of view. Only some recent items such as glazed earthenware were found in the modern soils, and very sparse materials (a few flakes) in the older layers. Yet the latter should probably be attributed to vertical migrations of materials, characteristic of sandy deposits (Gifford-Gonzalez et al., 1985; Balek, 2002), so the place where this trench was excavated probably lies outside the prehistoric settlement. No explanation could be found for the magnetic anomaly.

Test pit 8 was also excavated in 2014. It was opened $17 \mathrm{~m}$ east of Area 6 , in a place where an elongated positive anomaly, with two more intense sectors inside, was found. It was located on the eastern edge of the shell midden, very close to the slope that leads to the ponds. As in the previous case, the place was, in fact, outside the shell midden, as no shells - nor any other clear evidence of Mesolithic occupation - were found. Yet, there was a feature that might explain the anomaly: an oval-shaped concentration of sandstone blocks $(54 \times 13 \mathrm{~cm})$ in the upper part of a palaeosol that might be related to Phase $C$ at the site (SU 803). It might be interpreted as an anthropogenic accumulation of stones created during the sparse Neolithic occupation of the site.

Excavation area 9 was close to test pit 6, to the NW. There, some positive anomalies, similar to those tested in excavation area 6 , could be observed in the survey. We started in 2014 with a $4 \times 1 \mathrm{~m}$ trench, oriented west to east, but the interesting results that were obtained led us to extend it to the west and to the south that year and in 2015 to reach 12 square metres. This excavation area permitted us to detect and study the eastern edge of the Mesolithic shell midden, confirming that the human burial excavated in 2013 was outside it. The stratigraphy followed the pattern described for other trenches. Below the current surface (SU 901 and 902) we found the yellowish sands of Phase D (SU 903 and 920). Phase C was also found, and in this area it included several archaeological features such as a pit (SU 923) which contained several cattle (Bos taurus) bones (SU 922). It covered, in the central and western part of the trench, shell midden sediments (Phase B), whereas in the eastern part an archaeologically sterile sequence, similar to that described for excavation areas 7 and 8, was found. Evidence of fire could be defined in some areas at the bottom of the shell midden, including a hearth (SU 931), which was very close to the main anomaly detected in the survey. Below the shell midden a sandy layer with a much lower density of Scrobicularia plana fragments (SU 912), attributable to vertical movements of materials as those mentioned above, was found. To sum up, in the case of excavation area 9 , it appears that some anomalies might be related to the contrast between the shell midden and the relatively "clean" area east of it, enhanced by the effects of human activity, namely the use of fire in the former.

Excavation area 10 was opened in 2015. It was located in the southernmost limit of the site, where a large irregular positive anomaly was detected. We opened a $3 \times 1 \mathrm{~m}$ trench, oriented west to east, which was later enlarged in its eastern and central part $1 \mathrm{~m}$ to the north. There we found the typical sequence of the site, starting with the current soil (SU 1001 and 1002), then the yellowish sand of Phase D (SU 1003) and the Neolithic palaeosol (SU 1004 and 1007) above discrete sectors of shell midden (SU 1005,1006 and 1009), apparently separated by the removal of the intermediate parts by human activity during the Neolithic. At the base we found the sterile sand (SU 1008), showing in some areas intrusions of shell fragments (SU 1011). However, the shell midden did not appear in the western part of the trench. Instead, we found a trench (SU 1012) that reached the basal sandy layer, opened from SU 1004 and filled with blackish sand with a high density of sandstone blocks (SU 1007). This trench coincided with the positive anomaly, so it appears that this might reflect the difference between the "normal" stratigraphy of the site and the area affected by the mixing of the soil horizons. The high iron content of the local sandstone blocks in the trench may also have contributed to the contrast between the magnetic values found respectively in the western and in the central-eastern parts of the excavated area.

Finally, excavation area 11, opened in 2015 and still not completed, was intended to test a large positive anomaly, close to the west side of the track. A $2 \times 1 \mathrm{~m}$ trench oriented from west to east was opened, and later it was enlarged $1 \mathrm{~m}$ to the east. The stratigraphy showed again the five major units described above (surface, SU 1101 and 1102; Phase D: SU 1103; Phase C: SU 1104; Phase B: SU 1107, 1008, 1109, 1110, 1111, 1112, 1113, 1117, 1118, 1119, 1120 and 1121; substrate: SU 1116). However, there was a sharp difference between the western and the eastern part of the excavated area, the latter showing a complex series of salmon coloured shell layers filling a pit (SU 1114), whereas the former presented the typical characteristics of the shell midden deposits at the site. Some possible evidence of fire was found in the eastern part; but we will have to wait for results of the micromorphological analysis that one of the authors (C.D.) is carrying out to confirm this. However, it appears quite clear that the observed anomaly corresponds to the difference between the two kinds of shell midden sediment in this part of the site.

\section{Concluding remarks}

This research has been the first attempt to apply geophysical surveying techniques to the Mesolithic in Portugal. These methods, and particularly magnetic gradiometry, have been frequently employed for later periods, especially in the search for architectural structures, but no attempt had hitherto been made to use these techniques to locate the usually evanescent evidence of hunter-gatherer features. The results have been encouraging, yet 
technical and practical problems have emerged. It is evident, after the analysis of the magnetometry results obtained for both sites, and especially after the testing programme performed at Poças de São Bento, that the interpretation of the survey is quite complex. A straightforward, direct procedure to produce a map of the buried features is not possible. Yet the survey permits substantial progress in the knowledge of the site, and provides a very useful tool for planning excavations.

That is the case at Vale de Romeiras, a site where a very different picture from the previous results emerges from the geomagnetic survey, suggesting that the shell midden may actually be quite larger than expected. Obviously, the results need to be confirmed through the excavation of test pits, but that second stage in the research will depart from a very valuable orientation. The excavation can be planned to test concrete hypotheses derived from the survey. In any case it is most important to determine whether or not geomagnetic surveying is able to detect the limits of the shell concentration areas, a crucial issue for the interpretation of the Mesolithic settlement patterns in the Sado. The provisional results obtained in both sites suggest that the method might be useful for this purpose, but it has to be tested by excavating some test pits at Vale de Romeiras in the near future.

From another point of view, the testing fieldwork performed at Poças de São Bento has demonstrated that, although the interpretation remains difficult, geomagnetic surveying may be an efficient tool to find prehistoric features. As showed above, the results obtained at this site have been encouraging. Five cases out of six have provided Mesolithic or Neolithic features that appear to be related to the detected anomalies. The preliminary results partially confirm that the largest anomalies might reflect shell midden areas (excavation area 11), but they may also be related to other kind of features, such as large pits of trenches (excavation area 10). On the other hand, correlations have been found between smaller anomalies and anthropogenic structures such as burials, hearths or accumulations of blocks.

Thus, as in our previous experience in northern Spain (Arias et al., 2015a), geomagnetic surveying can be considered a rapid, relatively cheap and efficient method for locating Mesolithic structures. This is particularly important for large sites such as the Sado shell middens, where a good method for the evaluation of the archaeological content of the sites and further planning of the excavations is crucial. We also venture to suggest that this experience could be useful for other areas of Atlantic Europe where identifying evidence of late hunter-gatherer settlements is problematic.

\section{Acknowledgements}

The research reported in this paper has been developed within the framework of the projects 'Coastal transitions: a comparative approach to the processes of neolithization in Atlantic Europe' (COASTTRAN) (HAR2011-29907-C03-00; subproject HAR201129907-C03-01), granted by the VI Plan Nacional de Investigación Científica, Desarrollo e Innovación Tecnológica 2008-2011 and 'Coastal societies in a changing world: A diachronic and comparative approach to the Prehistory of SW Europe from the late Palaeolithic to the Neolithic' (CoChange) (HAR2014-51830-P), granted by the Plan Estatal de Investigación Científica y Técnica y de Innovación 2013-2016, both of the Spanish Ministry of Economy and Competitiveness. The excavations at Poças de São Bento were funded by those projects and by a grant from the Fundação para a Ciência e a Tecnologia ('Retorno ao Sado: Um caso entre os últimos caçadoresrecolectores e a emergência das sociedades agropastorís no sul de Portugal' (PTDC/HIS-ARQ/121592/2010), PI Mariana Diniz). Administrative authorisations were granted by the Direção Geral do Património Cultural of the Portuguese Government. We are also grateful to the Museu Nacional de Arqueologia, the Câmara Municipal de Alcácer do Sal and the Freguesia de Torrão. Special thanks are due to the generosity of the owner of Poças de São Bento, Dr. Miguel Portela de Morais (Moragri Sociedade Agrícola, S.A.), for his kind hospitality. We are also happy to acknowledge the valuable help of the Römisch-Germanische Kommission des Deutschen Archäologischen Instituts for allowing us to use their instruments. We particularly appreciate the most efficient collaboration of our colleagues Dr Friedrich Lüth (Berlin) and Dr Knut Rassmann (Frankfurt am Main). The GRASS tool "r.fill.gap" program used during the processing of our results has been developed by Benjamin Ducke. We would also like to acknowledge the contribution of an anonymous reviewer, who has helped us to improve the first version of this paper.

\section{References}

Araújo, A.C., 1995-1997. A indústria lítica do concheiro de Poças de S. Bento (Vale do Sado) no seu contexto regional. O Arqueólogo Português IV (13-15), 87-159. Araújo, A.C., Arias, P., Diniz, M.T., 2015. Lithics in a Mesolithic shell mound: new data from Poças de São Bento (Portugal). In: Bicho, N.F., Detry, C., Price, T.D., Cunha, E. (Eds.), Muge 150th: the 150th Anniversary of the Discovery of Mesolithic Shellmiddens, vol. 1. Cambridge Scholars Publishing, Cambridge, pp. 361-373.

Arias, P., Cubas, M., Fano, M.Á., Jordá, J., Salzmann, C., Teichner, F., et al., 2015a. Where are the "Asturian" dwellings? Preliminary results of an integrated survey programme on the late Mesolithic and the early Neolithic of northern Spain. Antiquity 89, 783-799.

Arias, P., Diniz, M.T., Araújo, A.C., Armendariz, Á., Teira, L.C., 2015b. At the edge of the marshes: new approaches to the Sado valley Mesolithic (southern Portugal). In: Bicho, N.F., Detry, C., Price, T.D., Cunha, E. (Eds.), Muge 150th: the 150th Anniversary of the Discovery of Mesolithic Shellmiddens, vol. 1. Cambridge Scholars Publishing, Cambridge, pp. 301-320.

Arnaud, J.M., 1989. The Mesolithic communities of the Sado valley, Portugal, in their ecological setting. In: Bonsall, C. (Ed.), The Mesolithic in Europe: Papers Presented at the Third International Symposium, Edinburgh 1985. John Donald, Edinburgh, pp. 614-631.

Arnaud, J.M., 1990. Le substrat mesolithique et le processus de neolithisation dans le sud du Portugal. In: Cahen, D., Otte, M. (Eds.), Rubané et Cardial. Actes du Colloque de Liège. Service de Préhistoire de la Université de Liège, Liège, pp. $437-446$.

Arnaud, J.M., 2000. Os concheiros mesolíticos do vale do Sado e a exploraçao dos recursos estuarinos (nos tempos pré-históricos e na actualidade). In: Actas do Encontro sobre Arqueologia da Arrábida. Instituto Português de Arqueologia, Lisboa, pp. 21-43.

Balek, C.L., 2002. Buried artifacts in stable upland sites and the role of bioturbation: a review. Geoarchaeology $17,41-51$.

Cepeda, J.J., Iglesias, J.M., Ruiz, A., Teichner, F., 2009a. La determinación del perímetro urbano de IULIOBRIGA (Cantabria). Prospecciones geofísicas en el sector de La Llanuca. Madrider Mitteilungen 50, 172-196.

Cepeda, J.J., Jiménez, J.I., Unzueta, M., Teichner, F., 2009b. El cerco de Bolunburu. Un recinto fortificado de la Edad del Hierro en Bizkaia. In: Medio siglo de Arqueología en el Cantábrico oriental y su entorno. Congreso Internacional. Vitoria 2007, pp. 883-894.

Costas, S., Jerez, S., Trigo, R.M., Goble, R., Rebêlo, L., 2012. Sand invasion along the Portuguese coast forced by westerly shifts during cold climate events. Quaternary Science Reviews 42, 15-28.

Cunha, E., Umbelino, C.I.S., 1995-1997. Abordagem antropológica das comunidades mesolíticas dos concheiros do Sado. O Arqueólogo Português IV (13-15), $161-179$.

Cunha, E., Umbelino, C.I.S., 2001. Mesolithic people from Portugal: an approach to Sado osteological series. Anthropologie 39, 125-132.

Diniz, M.T., 2010. O concheiro mesolítico do Cabeço das Amoreiras (S. Romão do Sado, Alcácer do (PTDC/HIS-ARQ/121592/2010) Sal): um (outro) paradigma perdido? In: Gibaja, J.F., Carvalho, A.F. (Eds.), Os últimos caçadores-recolectores e as primeiras comunidades produtoras do sul da Península Ibérica e do norte de Marrocos, Actas do Workshop (Faro, 2-4 de Novembro de 2009). Faculdade de Ciéncias Humanas e Sociais da Universidade do Algarve, Faro, pp. 49-61.

Diniz, M.T., Arias, P., 2012. O povoamento humano do paleo-estuário do Sado (Portugal): problemáticas em torno da ocupação dos concheiros mesolíticos. In: Almeida, A.C., Bettencourt, A.M.S., Moura, D., Monteiro-Rodrigues, S., Alves, M.I.C. (Eds.), Environmental changes and human interaction along the western Atlantic edge $=$ Mundanças ambientais e interação humana na fachada atlântica ocidental. APEQ-CITCEM-CEGOT-CGUP-CCT, Coimbra, pp. 139-157.

Diniz, M.T., Cubas, M., 2015. Pots for thought: Neolithic pottery in Sado Mesolithic shell middens. In: Bicho, N.F., Detry, C., Price, T.D., Cunha, E. (Eds.), Muge 150th: the 150th Anniversary of the Discovery of Mesolithic Shellmiddens, vol. 1. Cambridge Scholars Publishing, Cambridge, p. 375. 
Duarte, C., Iriarte, E., Diniz, M.T., Arias, P., 2015. High resolution XRF chemostratigraphy of the Poças de São Bento shell midden (Sado valley, Portugal). In: Bicho, N.F., Detry, C., Price, T.D., Cunha, E. (Eds.), Muge 150th: the 150th Anniversary of the Discovery of Mesolithic Shellmiddens, vol. 1. Cambridge Scholars Publishing, Cambridge, pp. 333-345.

Gifford-Gonzalez, D.P., Damrosch, D.B., Damrosch, D.R., Pryor, J., Thunen, R.L., 1985. The third dimension in site structure: an experiment in trampling and vertical dispersal. American Antiquity 50, 803-818.

Heleno, M., 1956. Um quarto de século de investigação arqueológica. O Arqueólogo Português II (3), 221-237.

Larsson, L., 1996. Late Atlantic settlement in southern Portugal. Results of an excavation of a Mesolithic shell midden by the River Sado. Current Swedish Archaeology 4, 123-139.

Larsson, L., 2010. Shells in the sand. Poças de São Bento - a Mesolithic shell midden by the River Sado, Southern Portugal. In: Armbruester, T., Hegewisch, M. (Eds.), Beiträge zur Vor- und Frühgeschichte der Iberischen Halbinsel und Mitteleuropas. Studien in honorem Philine Kalb. Dr. Rudolf Habelt, Bonn, pp. 23-43.

Linford, N., 2006. The application of geophysical methods to archaeological prospection. Reports on Progress in Physics 69, 2205-2257.

López-Dóriga, I., Diniz, M.T., Arias, P., 2015. New preliminary data on the exploitation of plants in Mesolithic shell middens: the evidence from plant macroremains from the Sado valley (Poças de São Bento and Cabeço do Pez). In: Bicho, N.F., Detry, C., Price, T.D., Cunha, E. (Eds.), Muge 150th: the 150th Anniversary of the Discovery of Mesolithic Shellmiddens, vol. 1. Cambridge Scholars Publishing, Cambridge, pp. 347-360.

Marchand, G., 2001. Les traditions techniques du Mésolithique final dans le sud de Portugal: les industries lithiques des amas coquilliers de Várzea da Mó et de Cabeço do Rebolador (fouilles M. Heleno). Revista Portuguesa de Arqueologia 4, 47-110.

Neubauer, W., 2001. Magnetische Prospektion in der Archäologie. Österreichische Akademie der Wissenschaften, Wien.

Nukushina, D., 2012. Tecno-tipologia lítica e cronometria no Mesolítico final do vale do Sado o caso do concheiro das Amoreiras (Alcacer do Sal) (unpublished MsSc thesis). Universidade de Lisboa. http://repositorio.ul.pt/handle/10451/7933.
Pimentel, N., Nukushina, D., Diniz, M.T., Arias, P., 2015. Lithic materials in the Sado River's shell middens - geological provenance and impact on site location. In: Bicho, N.F., Detry, C., Price, T.D., Cunha, E. (Eds.), Muge 150th: the 150th Anniversary of the Discovery of Mesolithic Shellmiddens, vol. 1. Cambridge Scholars Publishing, Cambridge, pp. 321-332.

Santos, M., Farinha, dos, Soares, J., Silva, C., Tavares, da, 1974. O concheiro epipaleolítico do Cabeço do Pez (Vale do Sado - Torrão). Primeira notícia. In: Actas do III Congresso Nacional de Arqueologia, Imprensa Portuguesa, Porto pp. $173-189$.

Scollar, I., Tabbagh, A., Hesse, A., Herzog, I., 1990. Archaeological Prospecting and Remote Sensing. Cambridge University Press, Cambridge.

Soares, J., 2013. Caçadores-recolectores semi-sedentários do Mesolítico do paleoestuário do Sado (Portugal). In: Soares, J. (Ed.), Pré-história das zonas húmidas: Paisagens de sal. Museu de Arqueologia e Etnografia do Distrito de Setúbal, Setúbal, pp. 13-56.

Teichner, F., Schneider, H., Höfer, D., Mäusbacher, R., Daut, G., 2014. Investigações geo-arqueológicas para a reconstituição da evolução do litoral algarvio durante o Holoceno. Revista Portuguesa de Arqueologia 17, 141-158.

Teichner, F., Oberhofer, K., Kopf, J., 2015. Miróbriga (Santiago do Cacém, Portogallo) Nuovi dati archeologici sul modello lusitano della residenza privata in età romana. In: Álvarez, J.M., Nogales, T., Rodà, I. (Eds.), Centro y periferia en el mundo clásico: Actas del XVIII Congreso Internacional de Arqueología Clásica, vol. II. Museo Nacional de Arte Romano, Mérida, pp. 1121-1124.

Umbelino, C.I.S., 2006. Outros sabores do passado: As análises de oligoelementos e de isótopos estáveis na reconstituição da dieta das comunidades humanas do Mesolítico Final e do Neolítico Final/Calcolítico do território português (unpublished $\mathrm{PhD}$ thesis). Universidade de Coimbra.

Umbelino, C.I.S., Cunha, E., 2012. The Sado shell middens: anthropological and palaeodietary depiction. In: Gibaja, J.F., Carvalho, A.F., Chambon, P. (Eds.) Funerary Practices in the Iberian Peninsula from the Mesolithic to the Chalcolithic. Archaeopress, Oxford, pp. 91-102.

Witten, A.J., 2006. Handbook of Geophysics and Archaeology. Equinox, Sheffield.

Zickgraf, B., 1999. Geomagnetische und geoelektrische Prospektion in der Archäologie: Systematik, Geschichte, Anwendung. M. Leidorf, Rahden. 